\title{
算料
}

\section{日本の造船における立向下進溶接棒の 実用化についで}

\author{
波辺正紀** 鎌田埧** \\ Practicability of Electrodes for Vertical \\ Downward Welding at Japanese Shipyards
}

By Masaki Watanabe \& Isao Kamada

\section{1. 緒言}

造船沈おける溶接作業中, 立向スミ溶接長は全体の 10\%以上にのばるので，日本においてはこれの能率问上 を重要な課題として造船所, 溶接棒メーカーが一体とな って研究をしてきた。

その結果として，信頼し得る下進溶接棒が落えられ泰 用化されるにいたった。

立何下進溶接が，いつ筫加ら行なわ机てきたかは明ら かではないが、パイプ溶接にセルローズ系被復溶接棒を 用いて溥板構造物，ボイラー娷管端のシール溶接を行な うことは，現在では広く知られている。

船体構造においてす说来立问下進溶接棒としてチタ二 ア系被愎溶接棒が一般に使用されてはいたが，その作業 性および機栈的性質に対する評洒は低く，したがってて の点から上部構造の一部に採用されていたに過ざない。

本報告でとり西げた，立向下進溶接棒は，乙れら上别 佪のもので，日枯に打いて独自儿開発研觉されてきたも のである，そしてその性能は，作業性の点においても， 従来のものに比へてて、沬るかに優れたものであるから， 船体のいかなる主姴静造部の溶接にも使用することがで きるものである。

この新しい立向下進溶接棒は，従来の塩基性型を立向 下准用に作業性を改良したものであり，その特徽を要約 すればつぎのようである。

1）熄基性被覆の溶接棒で苟るから，溶着金属は耐ワレ 性をはじめ，機械的性筫は優れており，いかなる棈造 部にも使用できる。

\footnotetext{
*原稿受付 昭和39年12月12日

**正貝大阪大学上学部（日本溶接拹会造船部会溶接施工委員会 委瞉長)

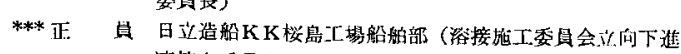
溶接小委只会委員艮)
}

口）溶接電流, 溶接速度, 棒角度などの溶接条件を適当 に選是すれば，十分なとけ込みす得られる，しかも作 業性法従来の上進溶接法に比べてはるか⿰亻や゙しい， 八）溶接経費は，従来の上進法に比へると，約 $1 / 21$ 诚少す る。

この信頼性のある立问下進溶接棒の出現は, 棒メ一力 一の熱心な研究と, 各造船所の強力な実用化への努力が 雪を結んだわけであり，造船に括ける溶接作業能率の向 上という点で画期的なすのがあった。

この棒は策用化されるや，わずかの期間にその利点は

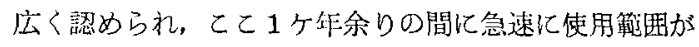
搪大されるにいたった。

われわれは本溶接法の適用範围を更化拡げ，船体強度 忉の，突合甘浴接にも適用すべく研究がつづけられてお り，その実用化も間もないととであるう。

\section{2.日本の造船における立向下進溶接の 実用化の現状}

\section{1 船体構造への心用実綪}

本溶接棒の利用は急進に倡びつつあり，ほとんどの造 船所がすでに䒠用化しており，またその使用筑团舌应大 しつつある。

そこで，こてでは実船への適用例の一部を表-2・1 および写真一 $2 \cdot 1 ， 2 \cdot 2$ に上り現状を紹介する。

\section{2 船体構造えの適用笪围}

この立问下進溶接棒は，開発後日も浅いので造船所に おいて产の適用籁拥は異なるが，大体はつぎのようであ る.

地上大組立作業は, 本溶接法が最む広く利用され，ま たその效果が如害に示される分野であり，スミ肉の大き さ $10 \mathrm{~mm}$ 以下の立向スミ肉溶接仙はほほ全面的使用 されるようになってきている。 
表一 $2 \cdot 1$ 立向下進溶接棒使用実績の一部

\begin{tabular}{|c|c|c|c|c|c|}
\hline 船の種類 & $\begin{array}{l}\text { TON 数 } \\
\text { (D.W.T) }\end{array}$ & $\begin{array}{c}\text { N.H.S.W } \\
\text { (TON) }\end{array}$ & 船級 & 完成年月 & 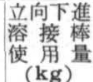 \\
\hline 見 本 市 船 & $(12,680) \mathrm{GT}$ & 3,900 & NK & 1962.11 & 1,500 \\
\hline 㛩石 運 搬 船 & 48,500 & 8,047 & NK & 1963. 5 & 1,100 \\
\hline 浚 渫 & $(8,000) \mathrm{PP}$ & 1,234 & - & 1963. 5 & 2,100 \\
\hline 油送 & 35,000 & 7,400 & L R & 1963.10 & 1,200 \\
\hline 货 物 & 12,000 & 3,000 & L R & 1963.12 & 1,600 \\
\hline 油 & 55,000 & 10,000 & NV & 1963.12 & 1,500 \\
\hline 油送 & 56,900 & 10,628 & L R & 1964. 2 & 5,500 \\
\hline 撤積 袋物船 & 24,500 & 3,421 & L R & 1964. 2 & 1,200 \\
\hline 連 & $(7,800) \mathrm{GT}$ & 2,193 & J G & 1964.2 & 1,220 \\
\hline 送 & 53,000 & 9,480 & N V & 1964. 3 & 1,500 \\
\hline 筷石運搬船 & 53,950 & 9,230 & N K & 1964. 3 & 3,000 \\
\hline 油 送 船 & 68,500 & 11,000 & L R & 1964. 3 & 5,000 \\
\hline セメント運搬船 & 12,000 & 2,400 & NK & 1964. 5 & 2,000 \\
\hline 貨 物 船 & 10,000 & 2,670 & L R & 1964. 7 & 1,000 \\
\hline
\end{tabular}

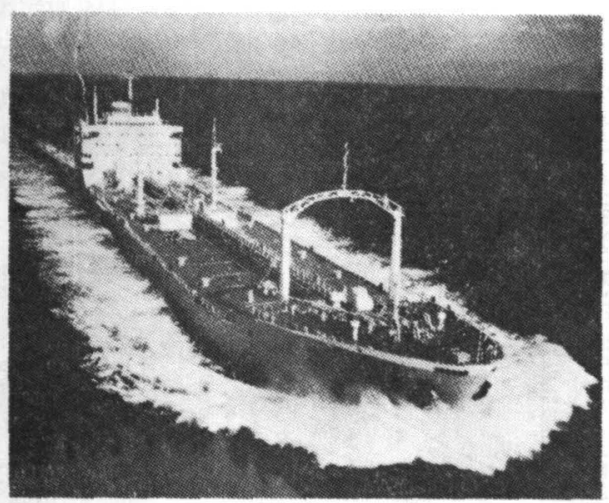

写真一 $2 \cdot 1$ 立向下進溶接適用船 (35,00 D.W.T. 油槽船)

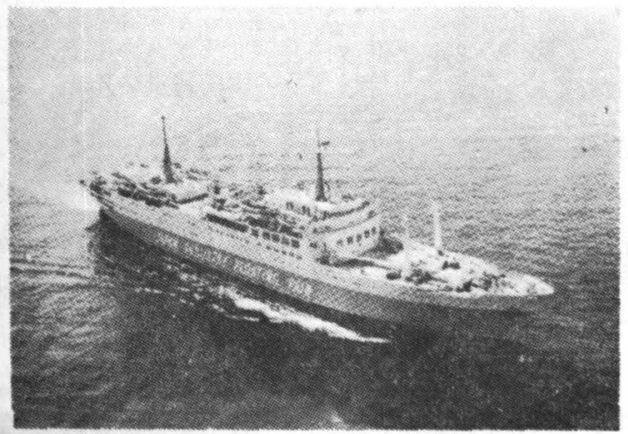

写真 $-2 \cdot 2$ 立向下進溶接適用船 $(12,600 \mathrm{GT}$ 見本市船)

この中でも，2重底フロアーメガーダー，タンカー の，ロンヂメンバーメトランスウエプ，八ウスウオール 継手などはその代表的な適用分野である.

船台作業においては, 外板 $\times$ W.T.B ${ }^{H D}$, W.T.B ${ }^{H D} \times$ W.T.B HD その他の T 継手および重ね継手などの立向ス ミ肉溶接について使用されている。 その一例を写真一
$2 \cdot 3,2 \cdot 4,2 \cdot 5,2 \cdot 6,2 \cdot 7,2 \cdot 8$ に示す.

\section{3 経 済 性}

今 50,000 D.W.T. タンカーを例にとり, 立向下進溶接 棒を全面的に利用したとすれば，この棒の予想使用量 は,

$\left.\begin{array}{ll}\text { 小組立作業 } & 0.3 \mathrm{TON} \\ \text { 大組立作業 } & 5.6 \mathrm{TON} \\ \text { 船 台作 業 } & 1.6 \mathrm{TON}\end{array}\right\}$ 計 $7.6 \mathrm{TON}$

となる. これは全立向スミ肉溶接の約 $68 \%$ に当り, 工数 の節減は約 $8,000 \mathrm{H}$ と推定される.

1 ) 溶接速度の向上

立向スミ肉溶接において, 本溶接棒を用いた下進溶接 法と, 従来から用いられているイルミナイト系溶接棒に よる上進溶接法上の単位溶接長当りの溶接時間を比較す

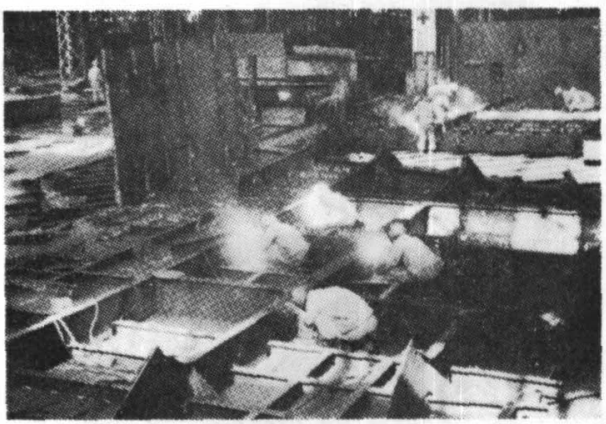

写真一 $2 \cdot 3$ 貨物船デッキガーダー, ピーム構造

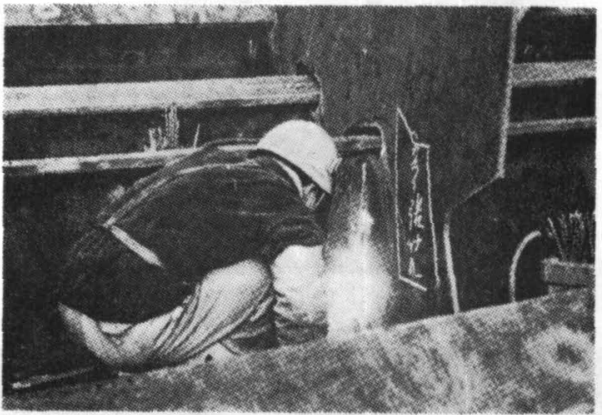

写真一 $2 \cdot 4$ 油槽船船底ロンヂ, トランス構造

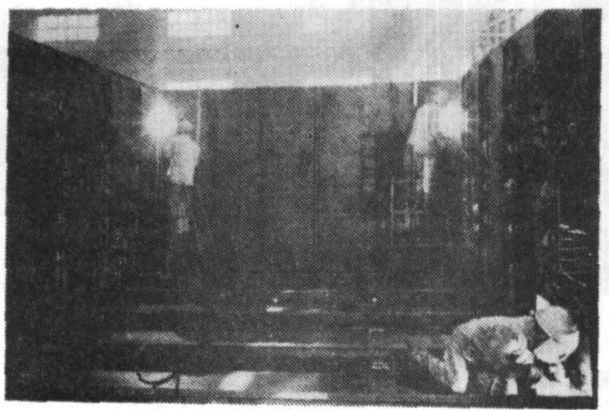

写真一 $2 \cdot 5$ 上部構造室壁 


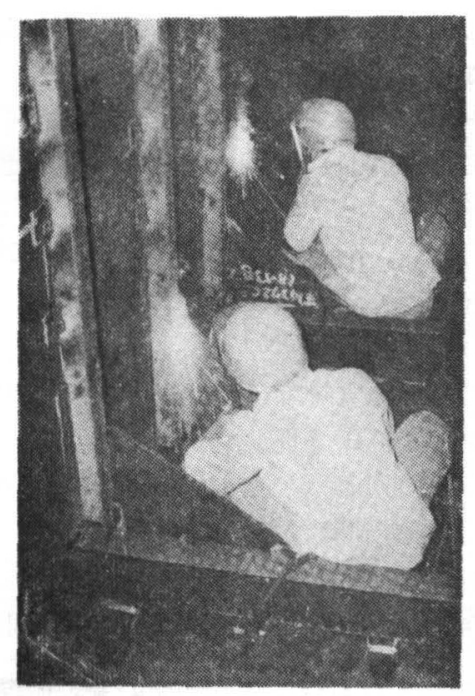

写真一 $2 \cdot 6$ 上部構造ビームブラケット

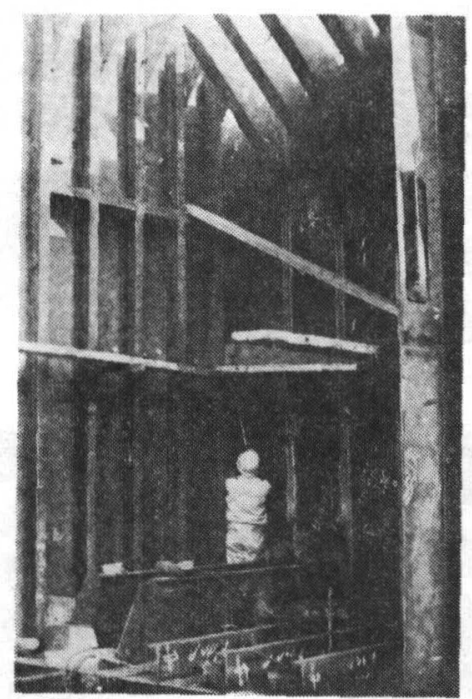

写真 $-2 \cdot 7$ 貨物船水密隔壁構造

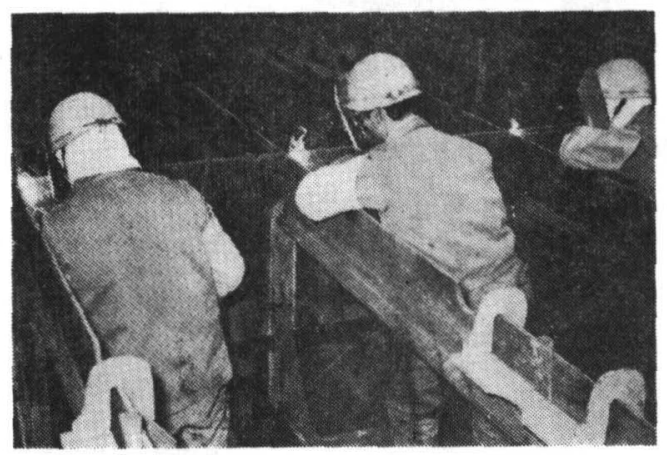

写真一 $2 \cdot 8$ 貨物船二重底構造

ると, 図一 $2 \cdot 1$ のようになり, 溶接時間は, 従来の上 進溶接法の 30〜60\%になる。これは使用電流が約 30\%

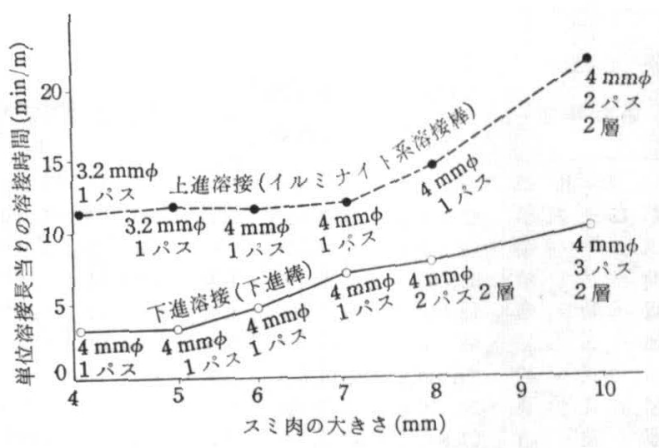

図-2・1 上進溶接と下進溶接との単位 溶接長当りの溶接間時の比較

高めに使用できるためである.

2) 溶接棒の節約

立向スミ肉溶接において, 本溶接棒を用いた下進溶接 法と, 従来加用いられているイルミナイト系溶接棒に よる上進溶接法との単位溶接長当りの棒消費量を比較す ると, 図一 $2 \cdot 2$ のようになり, イルミナイト系溶接棒 による上進溶接法の 60～70\% にとどまる.

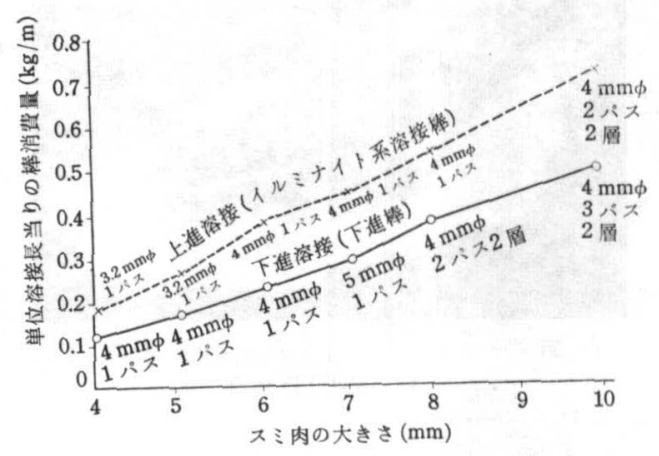

図 $2 \cdot 2$ 上進溶接と下進溶接との単位 溶接長当りの棒消費量の比較

3）経 費

立向スミ肉溶接において, 本溶接を用いた下進溶接法 とイルミナイト系溶接棒による上進溶接法との単位溶接 長当りの溶接経費（ここでは人件費と溶接棒費のみ採り 上げる）を比較して図一 $2 \cdot 3$ 亿示す.

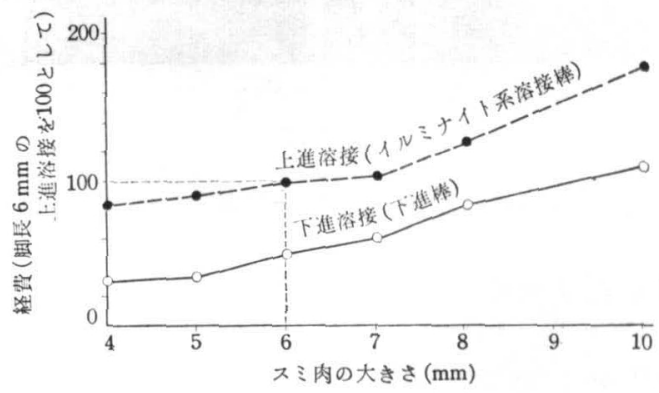

図- $2 \cdot 3$ 上進溶接上下進溶接との溶接経費の比較 
ここでは造船作業において，むっ上も作業量の多いス ミ肉の大きさ $6 \mathrm{~mm}$ の上進溶接を 100 として示す.

\section{3. 立向下進溶接棒の諸性質}

\section{1 一般特 性}

現在日木の主要溶接棒メーカーから市販されている立 向下進溶接棒は表一 $3 \cdot 1$ のごとくである．これらの溶 接棒の一般特性は次のとおりである.

表一 $3 \cdot 1$ 市販立向下進溶接棒

\begin{tabular}{|c|c|}
\hline 柄 & $x-$ - \\
\hline LB- $26 \mathrm{~V}$ & （株）神戸製錩所 \\
\hline (8) $-16 \mathrm{~V}$ & 八幡滀接棒（株） \\
\hline KS $-76 \mathrm{~V}$ & 川 崎 製 鉄 (株) \\
\hline LH $-50 \mathrm{D}$ & 富士溶 接棒 (株) \\
\hline
\end{tabular}

1 塩基性の被徣を施しており主として軟鋼および 50 キ 口高張力に使用されるものである．被覆の主成分は炭 酸カルシウムで他に脱酸剂, スラグ生成剂, 電弧安定 剂, 固着剂などを含んでおり，一般に使用されている 塩基性型低水素系溶接棒と異なる点は立向下進溶接に 適するように，粘性，表面張力の大きなスラグを生成 するようデザインされていることである.

2 溶着金属の機械的性質, 耐ワレ性と屯従来の低水素 系溶接棒と同程度にきわめてすぐれており，一般に使 用されているイル:ナイト系, ライムチタニヤ系, セ ルコーズ系, チタニヤ系溶接棒よりあ良い,

3 溶接部外観は立向上進法のそれと異なり, アンダー カット・オーパーラップなどの欠陥はほとんど発生せ ず,ビード波形の細かい下向溶接の場合と似た良好な 外観を呈する．一例を 写真一 $3 \cdot 1$ および $3 \cdot 2$ に示

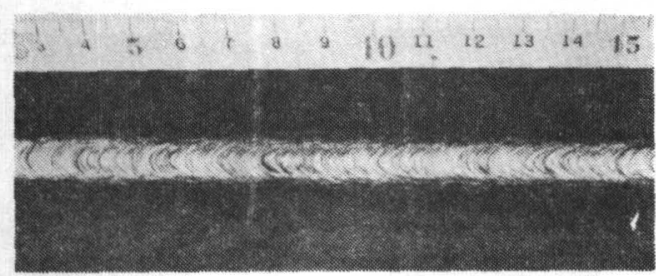

写真一 $3 \cdot 1$ ビード外観

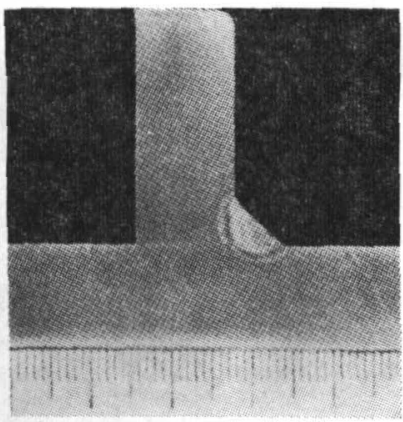

写真一 $3 \cdot 2$ ビード断面
す.

4 立向下進溶接は立向上進に比ぺてかなりの高電流の 使用が可能で, 溶接棒の溶融速度, したがって溶接速 度は飛躍的に大となりきわめて高能率となる。

5 溶接速度の速くなることにより, 溶接線単位長さ当 りの入熱量は減少し, このためひずみの発生量が減少 することが期待できる。

6 立向上進溶接は溶接技術としては比較的高級なもの で, 溶接工は相当の熟練を必要としているが立向下進 溶接は比較的容易に施行で可能で, 短期間の指導によ って十分良好な溶接部を得ることができる。

\section{2 溶着金属の性質}

1. 全溶着金属の機械的性質

全溶着金属の機械的性質を日本工業規格（JISZ 3211） にしたがって下向溶接による場合と立向下進溶接による 場合の両者において行なった試験結果の一例は表一 3 ・ 2 ，表一 $3 \cdot 3$ および 図- $3 \cdot 1$ に示すとおりで従来の 低水素溶接棒之同程度の性質を示している. 立向下進に よる場合は下向溶接の場合より引張強さ, 衙撃值いずれ もやや向上している。これはストレート運棒(立向下進) とウィピーング運棒（下向）による溶着法の相違による ものである.

\section{2. 溶着金属の化学成分}

全溶着金属の化学成分は 表一 $3 \cdot 4$ 亿示すとおりで, 立向下進溶接上下向溶接でとくに大きな差はみとめられ ないが, 立向下進溶接の場合のほうがアーク長が短いた め $\mathrm{Mn}, \mathrm{Si}$ がやや高く, $\mathrm{N}_{2}$ がやや低い傾向がある.

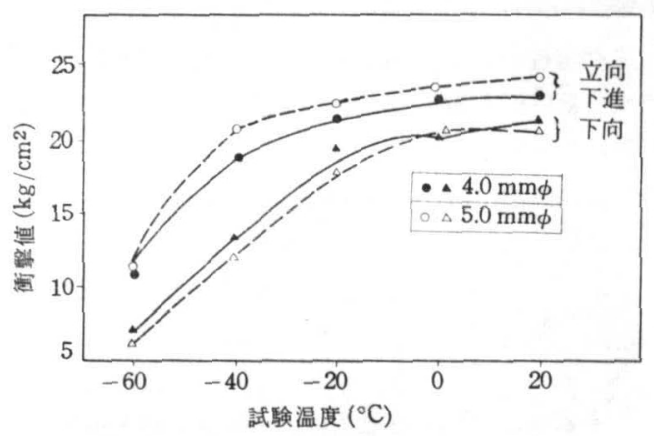

図- $3 \cdot 1$ 全溶着金属衝撃試験結果 $(2 \mathrm{mmV}$ ノッチシャルピー)

表 $-3 \cdot 2$ 全溶接着金属引張試験結果

\begin{tabular}{|c|c|c|c|c|c|c|}
\hline 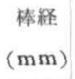 & 溶接姿勢 & $\begin{array}{l}\text { 溶接電流 } \\
\text { (Amp) }\end{array}$ & $\begin{array}{l}\text { 降休点 } \\
\mathrm{kg} / \mathrm{mm}^{2}\end{array}$ & $\begin{array}{c}\text { 引張強さ } \\
\mathrm{kg} / \mathrm{mm}^{2}\end{array}$ & $\begin{array}{l}\text { 伸 び } \\
50 \mathrm{~mm}\end{array}$ & $\begin{array}{l}\text { 絞 } \\
(\%)\end{array}$ \\
\hline \multirow{2}{*}{4.0} & 立向下進 & 190 & 45.8 & 53.9 & 34 & 74.6 \\
\hline & 下 向 & 190 & 42.5 & 52.3 & 33 & 75.4 \\
\hline \multirow{2}{*}{5.0} & 立向下進 & 240 & 46.4 & 54.3 & 33 & 73.8 \\
\hline & 下 向 & 240 & 42.3 & 52.5 & 35 & 75.0 \\
\hline
\end{tabular}


表一 $3 \cdot 3$ 全溶着金属衝撃試験結果

(2 mmVノッチシャルピー)

(単位: $\mathrm{kg} \cdot \mathrm{m} / \mathrm{cm}^{2}$ )

\begin{tabular}{|c|c|c|c|c|c|c|}
\hline \multirow{2}{*}{$\begin{array}{l}\text { 棒 径 } \\
(\mathrm{mm})\end{array}$} & \multirow{2}{*}{ 溶接威勢 } & \multicolumn{2}{|c|}{ 試 } & 温 & \multicolumn{2}{|l|}{${ }^{\circ} \mathrm{C}$} \\
\hline & & -60 & -40 & -20 & 0 & 20 \\
\hline \multirow{6}{*}{4.0} & & 9.2 & 18.8 & 22.1 & 23.2 & 22.5 \\
\hline & 立向下進 & 12.8 & 19.6 & 20.9 & 22.8 & 23.3 \\
\hline & & $(11.0)$ & $(19.2)$ & (21.5) & $(23.0)$ & $(22.9)$ \\
\hline & & 8.3 & 13.8 & 19.8 & 20.7 & 21.5 \\
\hline & 下 向 & 5.9 & 13.2 & 19.2 & 19.7 & 21.5 \\
\hline & & (7.1) & (13.5) & (19.5) & $(20.2)$ & 24.3 \\
\hline \multirow{6}{*}{5.0} & & 8.5 & 19.4 & 22.1 & 23.5 & 23.1 \\
\hline & 立向下進 & 13.9 & 22.6 & 22.9 & 23.5 & 25.5 \\
\hline & & (11.2) & $(21.0)$ & (22.5) & $(23.5)$ & $(24.3)$ \\
\hline & & 5.1 & 11.0 & 17.1 & 19.4 & 21.0 \\
\hline & 下 & 7.9 & 13.2 & 18.9 & 21.6 & 21.2 \\
\hline & & (6.5) & (12.1) & $(18.0)$ & (20.5) & (21.1) \\
\hline
\end{tabular}

註（）内は平均値を示す。

表 $-3 \cdot 4$ 溶着金属の化学成分の 1 例

\begin{tabular}{|c|c|c|c|c|c|c|c|}
\hline \multirow{2}{*}{$\begin{array}{c}\text { 棒径 } \\
(\mathrm{mm})\end{array}$} & \multirow{2}{*}{ 溶接姿勢 } & \multicolumn{3}{|c|}{ 化 } & 分 & \multicolumn{2}{|l|}{ (\%) } \\
\hline & & C & $\mathrm{Si}$ & $\mathrm{Mn}$ & $P$ & $\mathrm{~s}$ & $\mathrm{~N}_{2}$ \\
\hline \multirow{2}{*}{4.0} & 立向下進 & 0.07 & 0.52 & 1.01 & 0.021 & 0.009 & 0.007 \\
\hline & 下向 & 0.08 & 0.46 & 0.98 & 0.023 & 0.008 & 0.009 \\
\hline \multirow{2}{*}{5.0} & 立向下進 & 0.08 & 0.53 & 1.08 & 0.019 & 0.008 & 0.006 \\
\hline & 下向 & 0.08 & 0.41 & 1.02 & 0.019 & 0.008 & 0.011 \\
\hline
\end{tabular}

表一 $3 \cdot 5$ 溶着金属の水素量（c.c/100 gr）

\begin{tabular}{c|c|c|c}
\hline \hline 銘 柄 & 㧙散性水素 & 非㧙散性水素 & 全 水 素 \\
\hline $\mathrm{A}$ & 3.83 & 1.56 & 4.39 \\
\hline $\mathrm{B}$ & 3.96 & 1.78 & 5.74 \\
\hline
\end{tabular}

また溶着金属の水素試験の結果は 表一 $3 \cdot 5$ のとおり で水素量は低水素系溶接棒と同程度できわめて少ない. 試験は日木工業規格にしたがって拡散性水素量を測定し その後高温抽出法により非拡散性水素量を測定した.

3. 耐ワレ性

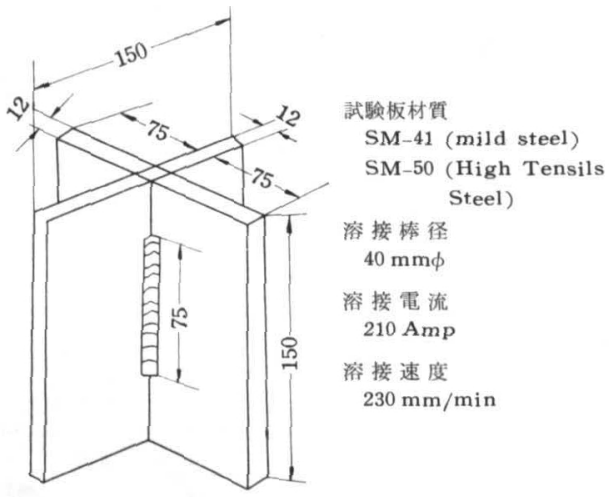

図- 3·2 十字スミ肉試験法
図一 $3 \cdot 2$ に示すような十字スミ肉試験法で立向下進 溶接により耐ワレ性をしらべた結果，軟鋼50キロ高張力 鋼いずれに対してもワレの発生はなく立向下進棒は十分 な耐ワレ性を有することが明らかである。

\section{3 立向下進溶接法の詳細}

前述のごとく立向下進溶接棒はきわめて優秀な性質を 有しているが，これが実用上良好な性能を発揮するため に必要な溶接条件について以下にのへる,

1 ビード外観形状

立向下進溶接においては溶接条件によりビード形状が 変るが, とくに溶接棒保持角度の影響が大きい. その角 度が垂直方向から $80^{\circ}$ 前後（図一 4 ・1）時がもっとも良 好なビード外観が得られ，それ以下の時は凹形になりや すい. 良好なビード外観を 写真一 $-3 \cdot 3$ に不良なビード 外観を 写真- $3 \cdot 4$ 亿示す.

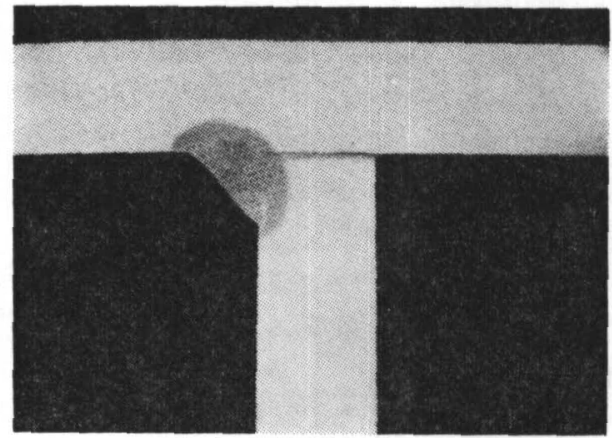

写真一 $3 \cdot 3$ 良好なピード

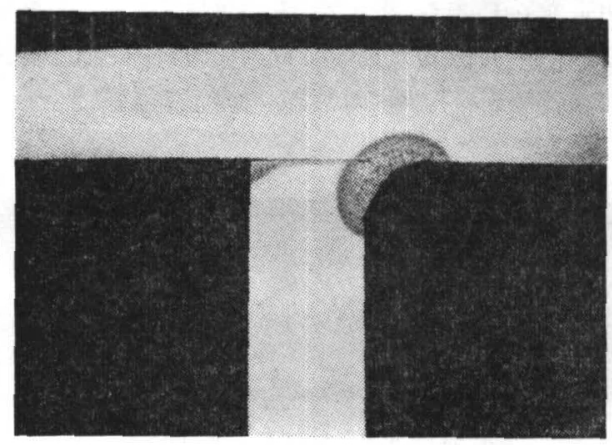

写真一 $3 \cdot 4$ 不良なビード

2 とけ込み

スミ肉の大きさ $5 \sim 7 \mathrm{~mm}$ を目標とし, 溶接条件がと け込みにおよぼす影響をしらべた結果を図一 $3 \cdot 4$, 図 $-3 \cdot 5$ に示す.ただし，てこでいうとけ込み（P）は 図一 $3 \cdot 3$ に示したものである.

溶接棒保持角度の増大にしたがってとけ込みは顕著に 増加し $80^{\circ}$ 程度が最良と考えられる。

溶接速度によっては，とけ込みはほとんど影響されな いが溶接電流の増大ではとけ込みはます. 


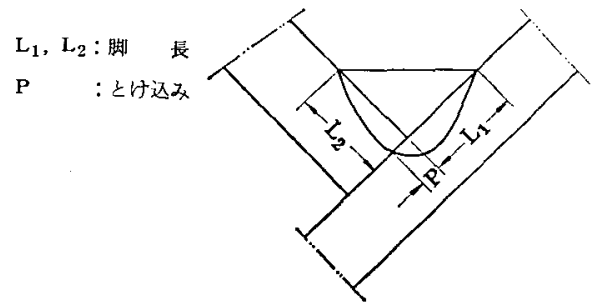

图-3・3上け込み

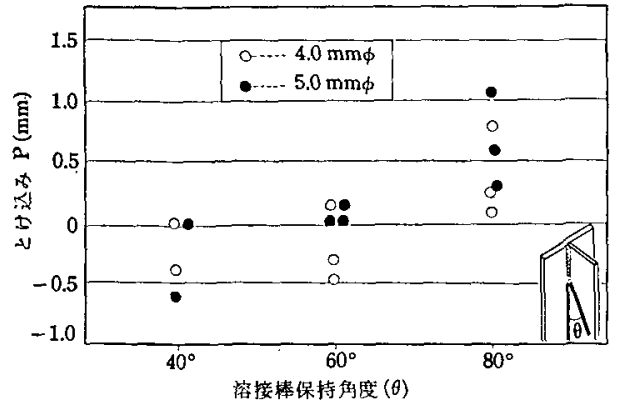

图-3・4 溶接棒角度ととけ边みの間係

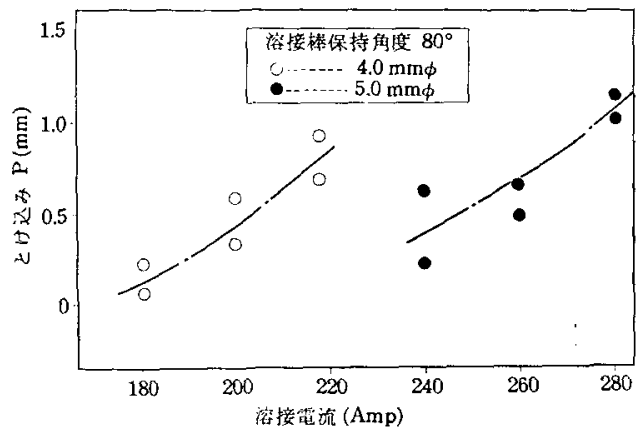

図-3・5 溶接電流上とけ込みの関係

3 スミ肉ルート間隙の影響

立向スミ肉下進溶接拖行の際のルート間隙がビード形 状と，とけ込みに及ばす影響をしらべた結果は，图一3

•6のでとくでルート間隙の大よなるにしたがい凹形ビ

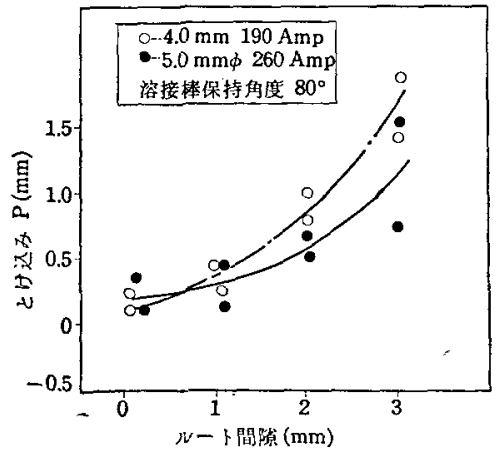

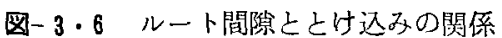
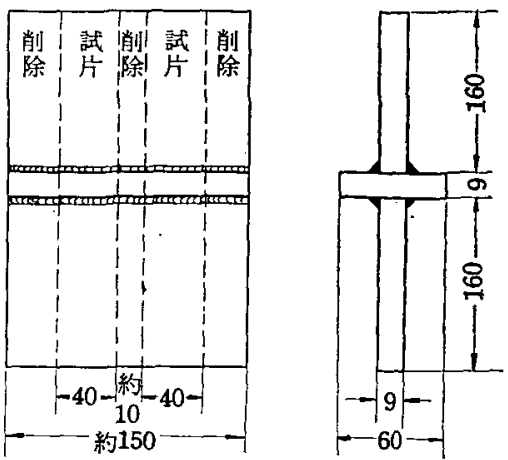

図-3・7十字スミ肉引張試験㑟

表一 3・6 ルート間隙と十字スミ肉引張試験結果

\begin{tabular}{|c|c|c|c|c|}
\hline 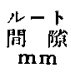 & $\begin{array}{c}\text { 尽肉溶接 } \\
\text { 椿の大きさ } \\
\text { mm }\end{array}$ & $\begin{array}{c}\text { 最大引强荷重 } \\
\mathrm{kg}\end{array}$ & $\begin{array}{l}\text { 引娠強き } \\
\mathrm{kg} / \mathrm{mm}^{2}\end{array}$ & 破断位睪 \\
\hline \multirow{4}{*}{0} & 5.28 & 16,200 & 54.3 & 溶着金属 \\
\hline & 558 & 17,100 & 54.2 & $"$ \\
\hline & 5.48 & 16,600 & 53.6 & " \\
\hline & 5.85 & 16,600 & 50.2 & $"$ \\
\hline \multirow{4}{*}{0.5} & 5.48 & 16,600 & 53.6 & $"$ \\
\hline & 5.18 & 16.800 & 52.3 & $"$ \\
\hline & 573 & 16.100 & 49.7 & $"$ \\
\hline & 5.28 & 16.700 & 55.9 & $"$ \\
\hline \multirow{4}{*}{1.0} & 5.25 & 17,500 & $>59.0$ & \\
\hline & 5.43 & 17,100 & 55.7 & 浴着余属 \\
\hline & 5.20 & 17.600 & 59.8 & $"$ \\
\hline & 5.45 & 16,900 & 54.8 & $"$ \\
\hline \multirow{4}{*}{1.5} & 5.08 & 17,700 & $>61.5$ & 般 \\
\hline & 5.20 & 17,600 & $>59.5$ & $"$ \\
\hline & 5.75 & 17,600 & 54.1 & 容着金属 \\
\hline & 5.43 & 17,700 & $>57.7$ & 母 材 \\
\hline \multirow{4}{*}{2.0} & 5.28 & 17,300 & $>57.9$ & $"$ \\
\hline & 5.20 & 17,600 & $>59.8$ & $"$ \\
\hline & 5.40 & 17,200 & $>56.3$ & $"$ \\
\hline & 5.05 & 17,600 & $>61.5$ & $"$ \\
\hline
\end{tabular}

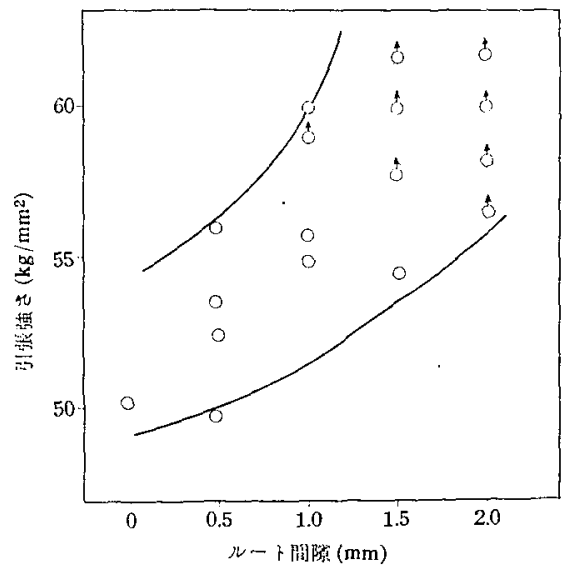

图-3・8 ルート間隙と引㖘道度 
一ドになる傾问があるが，とけ込みは深くなる。また， これがスミ肉溶接部の強度によ゙の程度影響を与えるか を, 図一 $3 \cdot 7$ の十字スミ肉引張試験により調查した。 結果は, 表一3・6ならび亿，図一3・8亿示すように 閏妳の大きくなった場合，上け込みの增大に上り強度は むしる增大するでとがわかる。

\section{4. 運棒の要領}

\section{11 層溶接}

溶接棒保持角度は，スミ肉を形成与る2枚の板に中央 線で 図ー4・1 のでとく溶接方向に対し 40〜90 で行な うが, 前述のごとく約 $80^{\circ}$ が良好である.

棒先端は, 被覆筒を母材倿触させて適正な速度と電 流で溶按する。

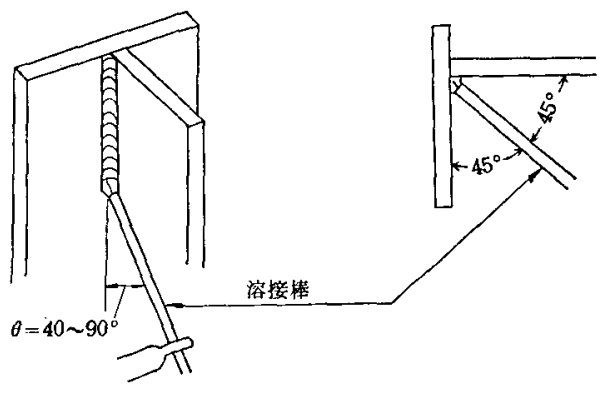

図-4・1 溶接棒保持度度

\section{2 ビードの継目}

ビードの継目は、ふつうにアークを切る上溶融金属が 下部にたれ下り，外観がわるくなり，と於込み毛減少し やすいので，図一 $4 \cdot 2$ のようにクレーターができるだ け，うすくなるようにアークを切る。

つぎに棒のスタートは，図ー4・3のように，やや下
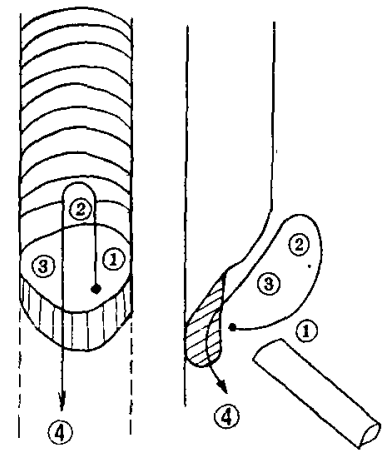

(1) 帮の上方にらか时。

(2) 算く押之つける。

(3) 押えつけたまっクレ 一ターK治って下 る。

(1) 凝深淔前のたれ下っ

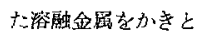
リ下にとばしてアー クを町る。

図-4・2 クレーター処理法
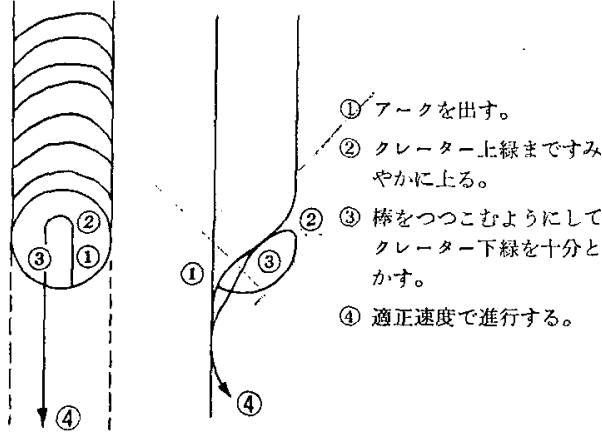

园-4・3 継目運榛法

カでアークを沖して，クレーターを十分うめてから進行 する。

\section{3 多層溶接}

大脚長又ミ肉には，多層溶接を行なうが，運棒上注永 すべき点は，1層溶接の場合とほぼ同様である。

2 層溶接法ししては，図-4・4 (a) (b) のでとく行 なうが（a） 2 パス洗では脚長 $8 \mathrm{~mm}$ 程度まで可能で (b) 3 パス法では $10 \mathrm{~mm}$ 程度まで, 凹形度の少ないス ミ肉を作りうる。

さらに大脚長のスミ肉溶接には，これらの組合せによ るマルテイパス法により高能率に溶接できる.

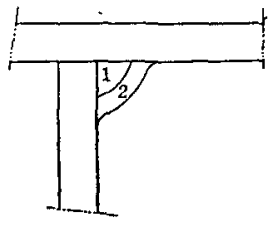

(a) 2 i:

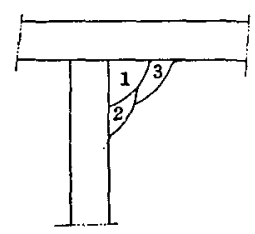

(b) 3 ; : x
図-4.42 厤溶接法

\section{5. 結垫}

立问下進棒は最近日本で開発されたるのであるが，本 論文に述べたように，各種の優秀な特性をもっているた め，次第にその使用籍囲が搪大される倾向にある.

しかし新しい溶接棒であるだけに，その作業時に，た とえば棒保持角度などについて，若干注意すべき点があ るのは当然である。

これらの点については将来さらに研究を進め，よりよ い下進溶接棒の開発に努力するつもりである.

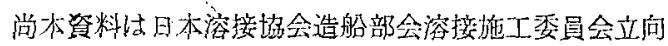
下進溶接小委員会の最終報告より抜すいしたものであ る. 